\title{
Morphometric variation of the common shrew Sorex araneus in Poland, in relation to karyotype
}

\author{
Jan M. WÓJCIK, Wiesław BOGDANOWICZ, Zdzisław PUCEK, \\ Anna M. WÓJCIK and Hanna ZALEWSKA
}

Wójcik J. M., Bogdanowicz W., Pucek Z., Wójcik A. M. and Zalewska H. 2000. Morphometric variation of the common shrew Sorex araneus in Poland, in relation to karyotype. [In: Evolution in the Sorex araneus group: Cytogenetic and molecular aspects. J. B. Searle and J. M. Wójcik, eds]. Acta Theriologica 45, Suppl. 1: 161-172.

Morphometric differentiation among six chromosome races of the common shrew Sorex araneus Linnaeus, 1758 in Poland was examined by the use of 26 orthogonal mandibular measurements in 388 specimens. The discriminant function analysis (DFA) performed on 21 morphological variables led to a correct classification in $59.3 \%$ of cases. Comparison of morphological and chromosomal distances showed that there is no significant agreement; the two matrices were apparently discordant (cophenetic correlation coefficient, $r_{\text {coph }}=0.216, p>0.05$ ). Multiple regression analysis revealed that $9.9 \%$ of the total morphological variance could be explained by eight geoclimatic variables. The DFA of residuals, remaining after regression of the morphological variables by the geoclimatic ones, let to correct assignment of only $26.3 \%$ specimens. Our research revealed that karyotypic divergence plays no important part in differentiating mandibular morphology in chromosome races of $S$. araneus, and morphological differences cannot be treated as a by-product of chromosomal speciation.

Mammal Research Institute, Polish Academy of Sciences, 17-230 Białowieża, Poland, e-mail: jwojcik@bison.zbs.bialowieza.pl (JMW, ZP, AMW, HZ); Museum and Institute of Zoology, Polish Academy of Sciences, Wilcza 64, 00-679 Warszawa, Poland, e-mail: wieslawb@robal.miiz.waw.pl (WB)

Key words: Sorex araneus, chromosome races, morphometrics, geoclimatic impact, Poland

\section{Introduction}

The common shrew Sorex araneus Linnaeus, 1758 is one of the several species of shrews which display clear chromosomal variation (see Zima et al. 1998). Recent surveys have revealed that there are at least 11 karyotypic races of $S$. araneus in Poland, which differ from each other in their set of metacentric chromosomes, and some of which come into contact and form zones of hybridization (Wójcik 1993, Fedyk 1995, see Searle and Wójcik 1998 for review). The distinct karyotypic differences which are observed in $S$. araneus might be expected to act as efficient barriers to gene flow between races. Nevertheless, studies of allozyme variation in this species have revealed relatively little genetic differentiation between karyotypic 
races in Sweden (Frykman et al. 1983), Britain (Searle 1985), and Poland (Wójcik and Wójcik 1994, Ratkiewicz et al. 2000).

Numerous hypotheses have been advanced to explain how selection might operate at the level of the chromosomal complement and how this process could relate to morphological divergence and speciation. So far, there have been a few publications that have focused on both morphological and karyological aspects of variation in $S$. araneus although the results obtained are somewhat ambiguous. For example, Sulkava et al. (1985) noted numerous significant local differences in the upper teeth of $S$. araneus in the Scandinavian Peninsula but this variation was not connected with the karyotypic differentiation. Similarly, W. Bogdanowicz and Z. Pucek (unpubl.) found no relationship between six skull measurements and the subdivision into the West and East European karyotypic groups occurring in Poland. Chętnicki et al. (1996) analysed four body measurements of S. araneus from three hybrid zones between various karyotypic races in northeastern Poland. Their study showed that in one zone the hybrids weighed less and were longer than individuals representing 'pure' races. Searle and Thorpe (1987) did not find any obvious difference in mandibular morphology between the karyotypic races of the common shrew in Britain. These authors suggest that geography is more important than karyotype as a morphological determinant.

The purpose of our research was to determine whether chromosomal races of $S$. araneus in Poland differ in mandibular morphology. Furthermore, we attempt to answer two other questions: (i) are the karyotypic races morphometrically recognisable with sufficient confidence? (ii) is there any pattern of morphological differentiation that may be interpreted in the light of established models of chromosomal speciation?

\section{Material and methods}

A total of 388 immature shrews from five chromosomal races, collected in 10 localities in Poland, were used (Table 1, Fig. 1). Based on research done by Wójcik (1993), samples from five localities (Nos. $1,3,6,7$ and 10) were classified to known chromosome races. The animals from other five localities were assigned to their putative races on the basis of the presumed ranges of those races. Samples Nos. 3,4 and 5 of the Stobnica race were pooled because they did not differ morphologically. The same was done for samples Nos. 7 and 8 of the Ulm race, and samples Nos. 9 and 10 of the Drnholec race. Sample No. 6 of the Ulm race from northern Poland and samples Nos. 7 and 8 of the Ulm race from southern Poland were analysed separately due to the large geographical distance between them (Fig. 1). Thus, six pooled samples, representing five different chromosome races, were finally used in this study. They belong either to the East European karyotypic group (EEKG - Białowieża and Łęgucki Młyn) or the West European karyotypic group (WEKG - Drnholec, Stobnica and Ulm) (Fig. 1).

Twenty-six orthogonal mandibular characters were measured on the left mandible of each shrew to the nearest $0.001 \mathrm{~mm}$ using a Wild measurescope (Fig. 2). The technique of measurement followed Hausser and Jammot (1974) and Hausser (1984). Because intraspecific variation reflects ontogenetic and sexual variation as well as any racial variation, the measurements that were obviously age-dependent (eg tooth wear) were avoided. Five variables (Nos. 8, 10, 11, 12 and 20; see Fig. 2) were sex-related and were also excluded from further analyses. The skull of the common shrew reaches essentially adult size during nestling development and therefore we did not test our data for 
Table 1. Samples of Sorex araneus from Poland used for morphometric study. $n$-sample size, samples numbered as in Fig. 1, * for details of karyotypes see Searle and Wójcik (1998).

\begin{tabular}{clccl}
\hline No. & \multicolumn{1}{c}{ Locality } & Geographic coordinates & $n$ & \multicolumn{1}{c}{ Chromosome race* } \\
\hline 1 & Białowieża & $52^{\circ} 42^{\prime} \mathrm{N}, \quad 23^{\circ} 55^{\prime} \mathrm{E}$ & 90 & Białowieża \\
2 & Górowo Iłowieckie & $54^{\circ} 18^{\prime} \mathrm{N}, 20^{\circ} 31^{\prime} \mathrm{E}$ & 43 & Łegucki Młyn \\
3 & Dziekanów Leśny & $52^{\circ} 21^{\prime} \mathrm{N}, 20^{\circ} 50^{\prime} \mathrm{E}$ & 30 & Stobnica \\
4 & Jedwabna & $52^{\circ} 31^{\prime} \mathrm{N}, 19^{\circ} 05^{\prime} \mathrm{E}$ & 29 & Stobnica \\
5 & Międzychód & $52^{\circ} 36^{\prime} \mathrm{N}, 15^{\circ} 54^{\prime} \mathrm{E}$ & 20 & Stobnica \\
6 & Stary Kraków & $54^{\circ} 27^{\prime} \mathrm{N}, 16^{\circ} 35^{\prime} \mathrm{E}$ & 46 & Ulm N \\
7 & Gościeradów & $50^{\circ} 52^{\prime} \mathrm{N}, 22^{\circ} 00^{\prime} \mathrm{E}$ & 12 & Ulm S \\
8 & Bratkowice & $50^{\circ} 07^{\prime} \mathrm{N}, 21^{\circ} 51^{\prime} \mathrm{E}$ & 42 & Ulm S \\
9 & Zielona & $50^{\circ} 32^{\prime} \mathrm{N}, 18^{\circ} 54^{\prime} \mathrm{E}$ & 31 & Drnholec \\
10 & Dębno & $51^{\circ} 11^{\prime} \mathrm{N}, 16^{\circ} 25^{\prime} \mathrm{E}$ & 45 & Drnholec \\
Total & & & & \\
\end{tabular}

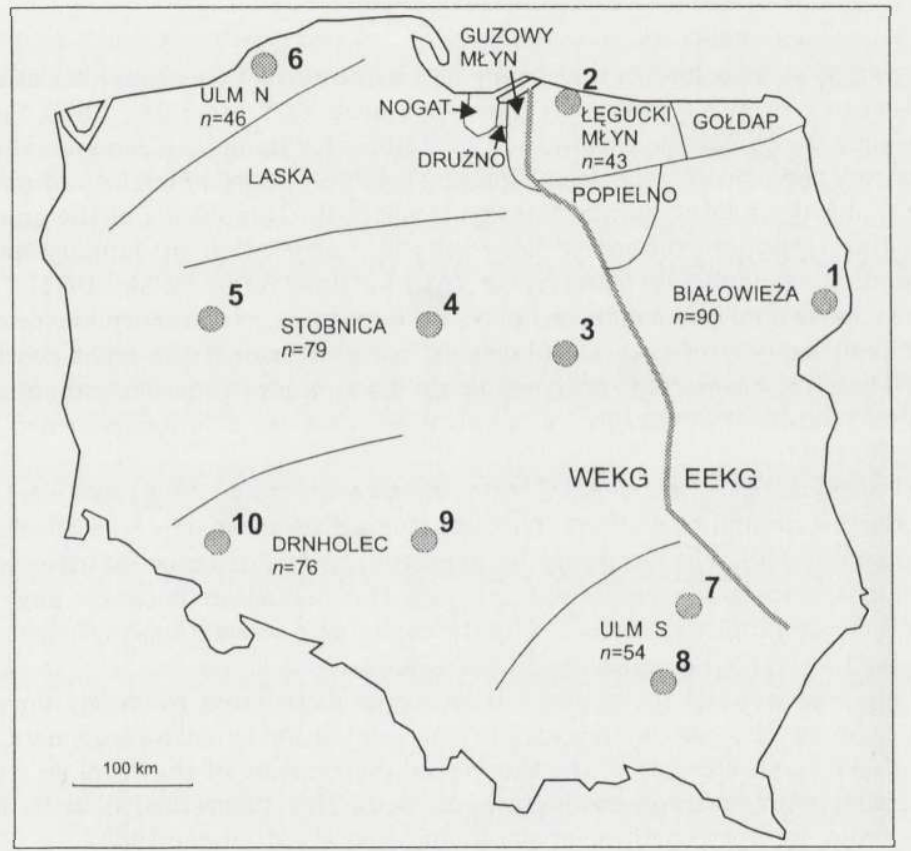

Fig. 1. Distribution of the samples of common shrews belonging to different chromosome races in Poland used for morphometric study. Names and approximate ranges of chromosome races (continuous lines) and the secondary contact zone between two karyotypic groups (thick dotted line) are shown (according to Wójcik 1993 and Fedyk 1995). Sample localities are numbered as in Table 1, $n$-sample size, EEKG - East European Karyotypic Group, WEKG - West European Karyotypic Group. 


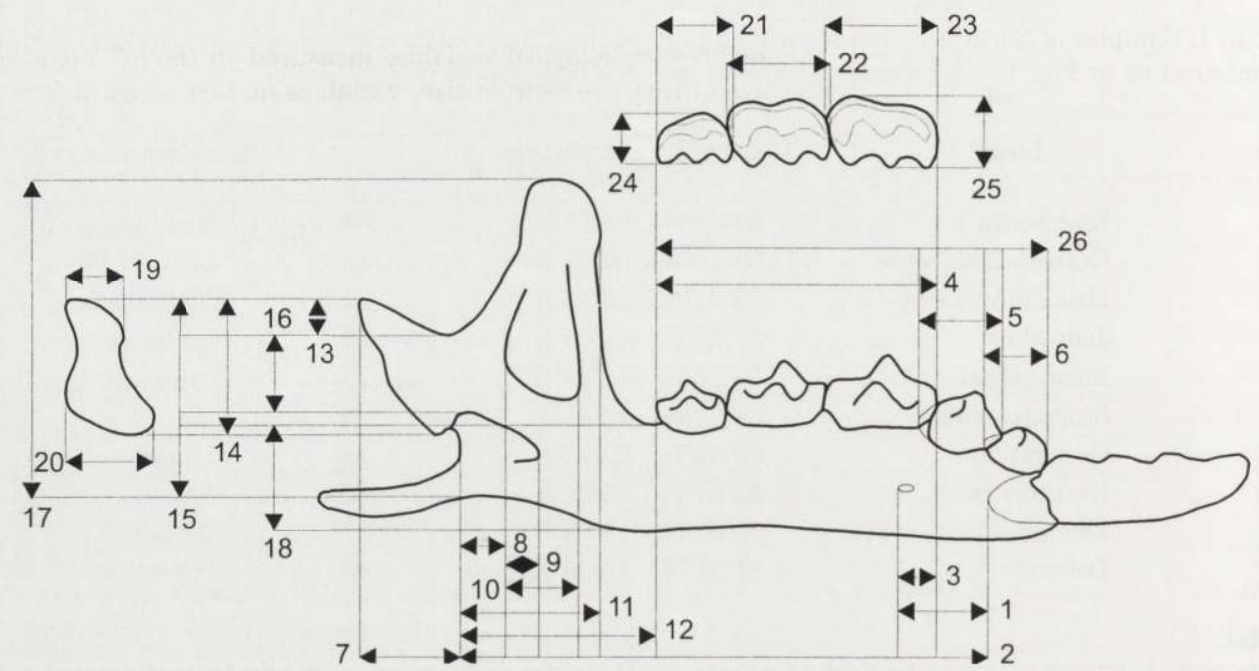

Fig. 2. Twenty-six orthogonal mandibular characters measured on the left mandible of the common shrew (after Hausser 1984, modified).

age-related size variation. It is known that brain case depth displays seasonal variation in shrews but mandibular dimensions are not significantly affected (Pucek 1970, Homolka 1980). Searle and Thorpe (1987) found no sign of ontogenetic variation in mandibles for immature common shrews in Britain.

Each locality was described by eight geoclimatic variables: geographical co-ordinates (latitude and longitude), height above sea level, annual average temperature, amplitude of the annual temperature variation, annual precipitation, difference between the precipitation in January and July, and the mean annual number of days with snow cover (Atlas Klimatyczny Polski 1971). To test whether adaptation to local environmental conditions plays an important role in morphological differentiation, a multiple regression analysis of each morphological variable against the eight geoclimatic variables was performed. These data were also analysed using discriminant function, canonical, and principal component analyses based, if applicable, on correlation matrices of untransformed variables (SPSS package by Norušis 1993).

Matrices of morphological (Euclidean) distances between chromosome races were computed using the centroids of the discriminant functions. The karyotypic distance matrix was calculated according to Rogers and Tanimoto (1960). The similarity between the various distance matrices was calculated by the product-moment correlation coefficient $(r)$, and the distortion between any matrix and the resulting UPGMA dendrogram was evaluated by the cophenetic correlation coefficient $\left(r_{\text {coph }}\right.$; Sokal and Sneath 1963) using the NTSYS-pc software (Rohlf 1993).

In order to test whether the interracial variance was distributed randomly for all the principal components we obtained, the part of this variance accounted for by each component (estimated by a discriminant analysis) was compared to the theoretical distribution of the "broken stick" (MacArthur 1957), using a Kolmogorov-Smirnov goodness of fit test. This theoretical distribution specifies the distribution of a finite quantity partitioned at random (see also Hausser 1984).

\section{Results}

All samples examined were morphologically very homogenous (Table 2). The discriminant function analysis (DFA) performed on 21 morphological variables 
Table 2. Means and standard errors for the 26 morphological variables measured on the left mandible of shrews belonging to different chromosome races. $n$-sample size, variables numbered as in Fig. 2.

\begin{tabular}{|c|c|c|c|c|c|c|}
\hline \multirow{2}{*}{$\begin{array}{c}\text { Variable } \\
\text { No. }\end{array}$} & \multicolumn{6}{|c|}{ Chromosome race } \\
\hline & $\begin{array}{c}\text { Białowieża } \\
\quad n=90\end{array}$ & $\begin{array}{l}\text { Lęgucki Młyn } \\
\quad n=43\end{array}$ & $\begin{array}{c}\text { Stobnica } \\
n=79\end{array}$ & $\begin{array}{l}\text { Ulm N } \\
n=46\end{array}$ & $\begin{array}{l}\text { Ulm S } \\
n=54\end{array}$ & $\begin{array}{c}\text { Drnholec } \\
n=76\end{array}$ \\
\hline 1 & $1.117 \pm 0.012$ & $1.122 \pm 0.016$ & $1.117 \pm 0.013$ & $1.134 \pm 0.019$ & $1.179 \pm 0.015$ & $1.106 \pm 0.016$ \\
\hline 2 & $6.830 \pm 0.018$ & $6.709 \pm 0.019$ & $6.732 \pm 0.019$ & $6.644 \pm 0.022$ & $6.858 \pm 0.019$ & $6.722 \pm 0.019$ \\
\hline 3 & $0.750 \pm 0.011$ & $0.815 \pm 0.017$ & $0.788 \pm 0.010$ & $0.795 \pm 0.014$ & $0.776 \pm 0.017$ & $0.724 \pm 0.012$ \\
\hline 4 & $3.795 \pm 0.008$ & $3.786 \pm 0.012$ & $3.752 \pm 0.009$ & $3.725 \pm 0.013$ & $3.826 \pm 0.012$ & $3.740 \pm 0.010$ \\
\hline 5 & $1.154 \pm 0.004$ & $1.136 \pm 0.007$ & $1.109 \pm 0.005$ & $1.108 \pm 0.006$ & $1.110 \pm 0.006$ & $1.110 \pm 0.006$ \\
\hline 6 & $1.034 \pm 0.005$ & $1.002 \pm 0.007$ & $0.986 \pm 0.006$ & $0.978 \pm 0.008$ & $0.991 \pm 0.006$ & $0.979 \pm 0.006$ \\
\hline 7 & $1.171 \pm 0.011$ & $1.203 \pm 0.014$ & $1.151 \pm 0.012$ & $1.181 \pm 0.013$ & $1.175 \pm 0.012$ & $1.159 \pm 0.010$ \\
\hline 8 & $0.509 \pm 0.013$ & $0.471 \pm 0.014$ & $0.514 \pm 0.010$ & $0.477 \pm 0.013$ & $0.493 \pm 0.012$ & $0.476 \pm 0.010$ \\
\hline 9 & $0.322 \pm 0.011$ & $0.362 \pm 0.016$ & $0.318 \pm 0.011$ & $0.363 \pm 0.017$ & $0.320 \pm 0.016$ & $0.326 \pm 0.012$ \\
\hline 10 & $1.120 \pm 0.010$ & $1.092 \pm 0.011$ & $1.091 \pm 0.009$ & $1.078 \pm 0.012$ & $1.114 \pm 0.010$ & $1.097 \pm 0.010$ \\
\hline 11 & $1.781 \pm 0.016$ & $1.702 \pm 0.021$ & $1.814 \pm 0.019$ & $1.689 \pm 0.023$ & $1.826 \pm 0.024$ & $1.765 \pm 0.017$ \\
\hline 12 & $2.638 \pm 0.012$ & $2.565 \pm 0.018$ & $2.614 \pm 0.013$ & $2.555 \pm 0.014$ & $2.604 \pm 0.014$ & $2.568 \pm 0.011$ \\
\hline 13 & $0.418 \pm 0.006$ & $0.424 \pm 0.008$ & $0.414 \pm 0.006$ & $0.417 \pm 0.009$ & $0.414 \pm 0.008$ & $0.396 \pm 0.006$ \\
\hline 14 & $1.554 \pm 0.008$ & $1.653 \pm 0.013$ & $1.582 \pm 0.011$ & $1.603 \pm 0.015$ & $1.595 \pm 0.010$ & $1.574 \pm 0.008$ \\
\hline 15 & $2.544 \pm 0.011$ & $2.551 \pm 0.019$ & $2.558 \pm 0.012$ & $2.527 \pm 0.017$ & $2.529 \pm 0.013$ & $2.498 \pm 0.015$ \\
\hline 16 & $0.835 \pm 0.007$ & $0.845 \pm 0.009$ & $0.840 \pm 0.007$ & $0.809 \pm 0.010$ & $0.829 \pm 0.008$ & $0.832 \pm 0.008$ \\
\hline 17 & $4.562 \pm 0.013$ & $4.512 \pm 0.018$ & $4.477 \pm 0.018$ & $4.401 \pm 0.020$ & $4.507 \pm 0.016$ & $4.394 \pm 0.013$ \\
\hline 18 & $1.231 \pm 0.006$ & $1.179 \pm 0.008$ & $1.213 \pm 0.005$ & $1.203 \pm 0.006$ & $1.185 \pm 0.006$ & $1.192 \pm 0.006$ \\
\hline 19 & $0.712 \pm 0.005$ & $0.669 \pm 0.008$ & $0.704 \pm 0.007$ & $0.728 \pm 0.008$ & $0.708 \pm 0.009$ & $0.711 \pm 0.007$ \\
\hline 20 & $1.194 \pm 0.006$ & $1.192 \pm 0.012$ & $1.213 \pm 0.008$ & $1.211 \pm 0.008$ & $1.237 \pm 0.009$ & $1.236 \pm 0.008$ \\
\hline 21 & $1.000 \pm 0.003$ & $1.008 \pm 0.005$ & $1.000 \pm 0.004$ & $1.003 \pm 0.005$ & $1.011 \pm 0.005$ & $1.003 \pm 0.004$ \\
\hline 22 & $1.271 \pm 0.004$ & $1.278 \pm 0.003$ & $1.278 \pm 0.004$ & $1.267 \pm 0.005$ & $1.283 \pm 0.004$ & $1.277 \pm 0.003$ \\
\hline 23 & $1.560 \pm 0.004$ & $1.573 \pm 0.004$ & $1.560 \pm 0.004$ & $1.560 \pm 0.005$ & $1.572 \pm 0.004$ & $1.574 \pm 0.004$ \\
\hline 24 & $0.702 \pm 0.003$ & $0.720 \pm 0.004$ & $0.717 \pm 0.004$ & $0.711 \pm 0.006$ & $0.719 \pm 0.005$ & $0.725 \pm 0.004$ \\
\hline 25 & $0.972 \pm 0.004$ & $0.986 \pm 0.007$ & $0.978 \pm 0.006$ & $0.958 \pm 0.008$ & $0.971 \pm 0.007$ & $0.984 \pm 0.006$ \\
\hline 26 & $5.459 \pm 0.012$ & $5.388 \pm 0.016$ & $5.337 \pm 0.014$ & $5.311 \pm 0.016$ & $5.441 \pm 0.014$ & $5.356 \pm 0.014$ \\
\hline
\end{tabular}

$(n=388)$ led to a correct classification in $59.3 \%$ of cases (Table 3). Such a low percentage suggests that no obvious morphological differences exist between the chromosome races of $S$. araneus in Poland.

A multiple regression analysis of each morphological variable against the eight geoclimatic variables allowed the total morphological variance which can be explained by climate and geography to be estimated, and generated the morphological residuals uncorrelated with these factors. As evident from the determination coefficient $\left(r^{2}\right), 2.7-21.7 \%$ of the variance of each variable is accounted for by geoclimatic variables and, on average, only $9.8 \%$ of the total morphological variance was directly related to climate and geographic location (Table 4). 
Table 3. Classification results of the discriminant analysis on the 21 morphological variables and on the residuals remaining after regression of the morphological variables by the geoclimatic factors.

\begin{tabular}{|c|c|c|c|c|c|c|c|}
\hline \multirow{2}{*}{ Actual race } & \multirow{2}{*}{$n$} & \multicolumn{6}{|c|}{ Predicted race membership (number and percentage) } \\
\hline & & 1 & 2 & 3 & 4 & 5 & 6 \\
\hline \multicolumn{8}{|c|}{ Morphological variables } \\
\hline $\begin{array}{l}\text { Białowieża } \\
\text { (1) }\end{array}$ & 90 & $\begin{array}{l}68 \\
75.5\end{array}$ & $\begin{array}{l}2 \\
2.2\end{array}$ & $\begin{array}{l}4 \\
4.4\end{array}$ & $\begin{array}{l}4 \\
4.4\end{array}$ & $\begin{array}{c}9 \\
10.0\end{array}$ & $\begin{array}{l}3 \\
3.3\end{array}$ \\
\hline $\begin{array}{l}\text { Łçgucki Młyn } \\
\text { (2) }\end{array}$ & 43 & $\begin{array}{l}1 \\
2.3\end{array}$ & $\begin{array}{l}28 \\
65.1\end{array}$ & $\begin{array}{c}7 \\
16.3\end{array}$ & $\begin{array}{l}1 \\
2.3\end{array}$ & $\begin{array}{l}3 \\
7.0\end{array}$ & $\begin{array}{l}3 \\
7.0\end{array}$ \\
\hline $\begin{array}{l}\text { Stobnica } \\
\text { (3) }\end{array}$ & 79 & $\begin{array}{l}7 \\
8.9\end{array}$ & $\begin{array}{c}9 \\
11.4\end{array}$ & $\begin{array}{l}35 \\
44.3\end{array}$ & $\begin{array}{l}5 \\
6.3\end{array}$ & $\begin{array}{l}6 \\
7.6\end{array}$ & $\begin{array}{l}17 \\
21.5\end{array}$ \\
\hline $\begin{array}{l}\text { Ulm } N \\
\text { (4) }\end{array}$ & 46 & $\begin{array}{l}2 \\
4.3\end{array}$ & $\begin{array}{l}3 \\
6.5\end{array}$ & $\begin{array}{l}3 \\
6.5\end{array}$ & $\begin{array}{l}27 \\
58.7\end{array}$ & $\begin{array}{l}3 \\
6.5\end{array}$ & $\begin{array}{c}8 \\
17.4\end{array}$ \\
\hline $\begin{array}{l}\text { Ulm } S \\
(5)\end{array}$ & 54 & $\begin{array}{l}2 \\
3.7\end{array}$ & $\begin{array}{c}6 \\
11.1\end{array}$ & $\begin{array}{l}3 \\
5.6\end{array}$ & $\begin{array}{l}1 \\
1.9\end{array}$ & $\begin{array}{l}34 \\
63.0\end{array}$ & $\begin{array}{c}8 \\
14.8\end{array}$ \\
\hline $\begin{array}{l}\text { Drnholec } \\
\text { (6) }\end{array}$ & 76 & $\begin{array}{l}7 \\
9.2\end{array}$ & $\begin{array}{l}7 \\
9.2\end{array}$ & $\begin{array}{l}10 \\
13.2\end{array}$ & $\begin{array}{c}9 \\
11.8\end{array}$ & $\begin{array}{l}5 \\
6.6\end{array}$ & $\begin{array}{l}38 \\
50.0\end{array}$ \\
\hline \multicolumn{8}{|c|}{ Residuals } \\
\hline $\begin{array}{l}\text { Białowieża } \\
\text { (1) }\end{array}$ & 90 & $\begin{array}{l}7 \\
7.8\end{array}$ & $\begin{array}{l}8 \\
8.9\end{array}$ & $\begin{array}{l}18 \\
20.0\end{array}$ & $\begin{array}{l}6 \\
6.7\end{array}$ & $\begin{array}{l}11 \\
12.2\end{array}$ & $\begin{array}{l}40 \\
44.4\end{array}$ \\
\hline $\begin{array}{l}\text { Łęgucki Młyn } \\
\text { (2) }\end{array}$ & 43 & $\begin{array}{l}4 \\
9.3\end{array}$ & $\begin{array}{c}5 \\
11.6\end{array}$ & $\begin{array}{l}10 \\
23.3\end{array}$ & $\begin{array}{l}3 \\
7.0\end{array}$ & $\begin{array}{c}9 \\
20.9\end{array}$ & $\begin{array}{l}12 \\
27.9\end{array}$ \\
\hline $\begin{array}{l}\text { Stobnica } \\
\text { (3) }\end{array}$ & 79 & $\begin{array}{l}5 \\
6.3\end{array}$ & $\begin{array}{c}8 \\
10.1\end{array}$ & $\begin{array}{l}5 \\
6.3\end{array}$ & $\begin{array}{c}8 \\
10.1\end{array}$ & $\begin{array}{l}32 \\
40.5\end{array}$ & $\begin{array}{l}21 \\
26.6\end{array}$ \\
\hline $\begin{array}{l}\text { Ulm N } \\
(4)\end{array}$ & 46 & $\begin{array}{c}9 \\
19.6\end{array}$ & $\begin{array}{l}3 \\
6.5\end{array}$ & $\begin{array}{c}5 \\
10.9\end{array}$ & $\begin{array}{l}3 \\
6.5\end{array}$ & $\begin{array}{l}13 \\
28.3\end{array}$ & $\begin{array}{l}13 \\
28.3\end{array}$ \\
\hline $\begin{array}{l}\text { Ulm } S \\
(5)\end{array}$ & 54 & $\begin{array}{l}4 \\
7.4\end{array}$ & $\begin{array}{l}0 \\
0\end{array}$ & $\begin{array}{c}6 \\
11.1\end{array}$ & $\begin{array}{l}1 \\
1.9\end{array}$ & $\begin{array}{l}36 \\
66.7\end{array}$ & $\begin{array}{c}7 \\
13.0\end{array}$ \\
\hline $\begin{array}{l}\text { Drnholec } \\
(6)\end{array}$ & 76 & $\begin{array}{l}5 \\
6.6\end{array}$ & $\begin{array}{l}4 \\
5.3\end{array}$ & $\begin{array}{c}8 \\
10.5\end{array}$ & $\begin{array}{l}3 \\
3.9\end{array}$ & $\begin{array}{l}10 \\
13.2\end{array}$ & $\begin{array}{l}46 \\
60.5\end{array}$ \\
\hline
\end{tabular}

The canonical variate analysis revealed that canonical functions of morphological and geoclimatic variates do not correlate significantly (Table 5) and there are no obvious transracial clines. The first morphological variate accounted for only $7.6 \%$ of the total morphological variance; in this particular case, $4.1 \%$ of the total morphological variance could be explained by the geoclimatic factors. The remaining seven functions explained on even lower percentage of the morphological variability (Table 5).

The DFA performed on the residuals remaining after regression of morphological variables by the geoclimatic ones, allowed only $26.3 \%$ specimens to be assigned to 
Table 4. Correlation $(r)$ and determination coefficients $\left(r^{2}\right)$ of the 21 morphological variables in relation to the geoclimatic factors. Variables numbered as in Fig. 2.

\begin{tabular}{lcc}
\hline Variable No. & $r$ & $r^{2}$ \\
\hline 1 & 0.189 & 0.036 \\
2 & 0.400 & 0.160 \\
3 & 0.285 & 0.081 \\
4 & 0.352 & 0.124 \\
5 & 0.403 & 0.162 \\
6 & 0.400 & 0.160 \\
7 & 0.222 & 0.049 \\
9 & 0.232 & 0.052 \\
13 & 0.163 & 0.027 \\
14 & 0.407 & 0.165 \\
15 & 0.169 & 0.029 \\
16 & 0.198 & 0.039 \\
17 & 0.418 & 0.175 \\
18 & 0.397 & 0.157 \\
19 & 0.345 & 0.119 \\
21 & 0.233 & 0.054 \\
22 & 0.218 & 0.048 \\
23 & 0.253 & 0.064 \\
24 & 0.285 & 0.081 \\
25 & 0.245 & 0.060 \\
26 & 0.466 & 0.217 \\
Mean & & 0.098 \\
& 0.299 &
\end{tabular}

Table 5. Relationships between the canonical functions of the morphological and geoclimatic variates. None of these function pairs correlate significantly with each other. The total morphological variance explained is the percentage of morphological variance accounted by geoclimatic variables.

\begin{tabular}{lccccc}
\hline $\begin{array}{l}\text { Morphological } \\
\text { vs geoclimatic } \\
\text { function pair }\end{array}$ & Eigenvalue & $\begin{array}{c}\text { Canonical } \\
\text { correlation }\end{array}$ & $\begin{array}{c}\text { Total } \\
\text { morphological } \\
\text { variance (\%) }\end{array}$ & $\begin{array}{c}\text { Total } \\
\text { morphological } \\
\text { variance } \\
\text { explained (\%) }\end{array}$ & Wilk's lambda \\
\hline 1 & 0.539 & 0.734 & 7.6 & 4.1 & 0.138 \\
2 & 0.301 & 0.549 & 6.3 & 1.9 & 0.299 \\
3 & 0.260 & 0.510 & 6.2 & 1.6 & 0.427 \\
4 & 0.187 & 0.433 & 2.7 & 0.5 & 0.578 \\
5 & 0.164 & 0.405 & 5.5 & 0.9 & 0.711 \\
6 & 0.087 & 0.295 & 6.9 & 0.6 & 0.851 \\
7 & 0.050 & 0.223 & 4.0 & 0.2 & 0.931 \\
8 & 0.020 & 0.140 & 5.0 & 0.1 & 0.980 \\
Total & & & 44.2 & 9.9 & \\
\hline
\end{tabular}




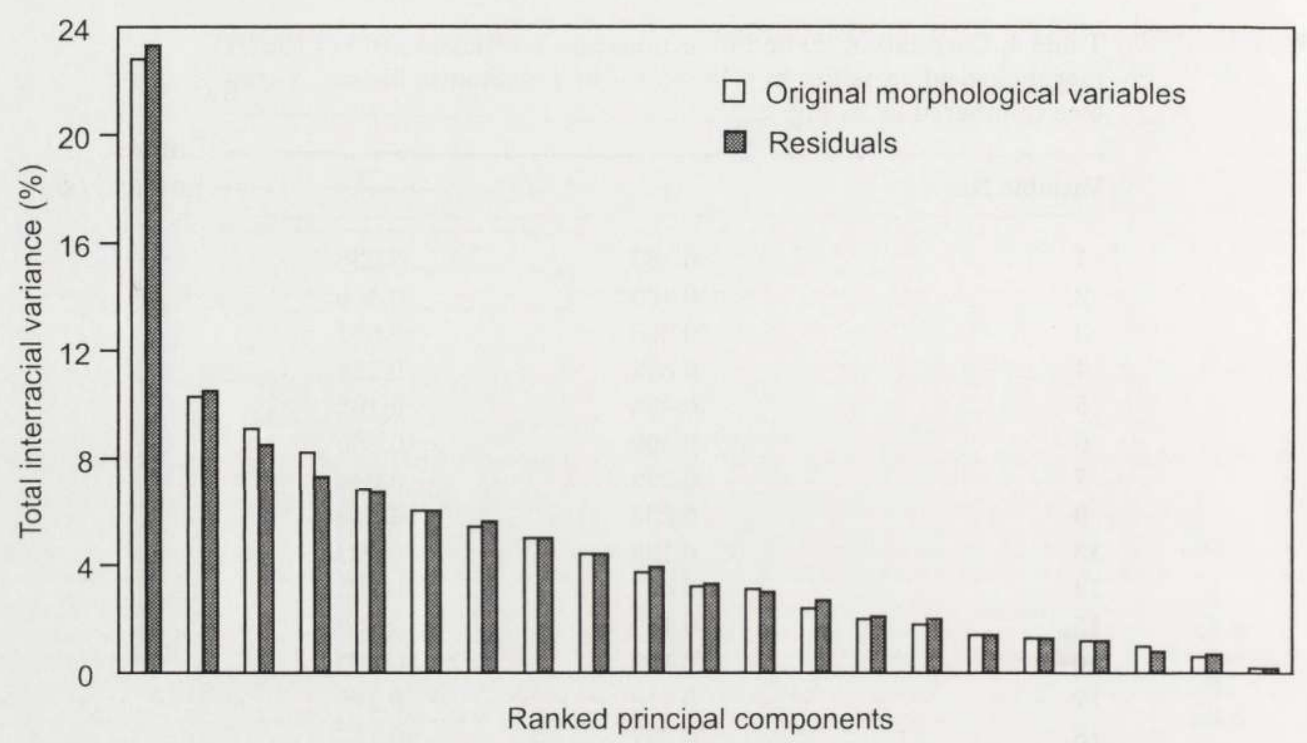

Fig. 3. Distribution of the interracial variance of the principal components computed on the original morphological characters and their residuals after removing the effect of eight geoclimatic variables. Principal components are ranked following their decreasing contribution to interracial variance.

their actual chromosome races correctly (see Table 3), and confirmed no clear differences in their mandibular morphology.

The results of principal component analyses of both the original morphological variables and the residuals showed that the interracial variance accounted for by each principal component was randomly distributed on different morphological features (Fig. 3). A Kolmogorov-Smirnov goodness of fit test indicated that the two observed distributions do not differ significantly from expectation $(p>0.4$ in both cases).

The comparison of the matrices of global morphological and chromosomal distances revealed that there is no significant agreement between them (Fig. 4); they were apparently discordant $(r=0.216, p>0.05)$. A similar result was obtained when comparing the matrices of residual morphological and chromosomal distances $(r=0.391, p>0.05)$.

\section{Discussion}

In the present study we examined races of the East European and West European karyotypic groups (EEKG and WEKG, respectively). One might expect larger morphological differences between races belonging to different chromosome groups than between races of the same group. Our results do not support this 


\section{A global morphological distances}

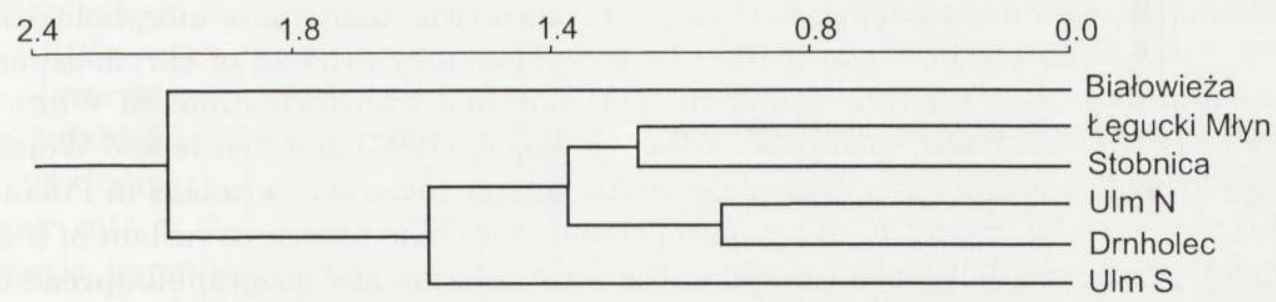

B chromosomal distances

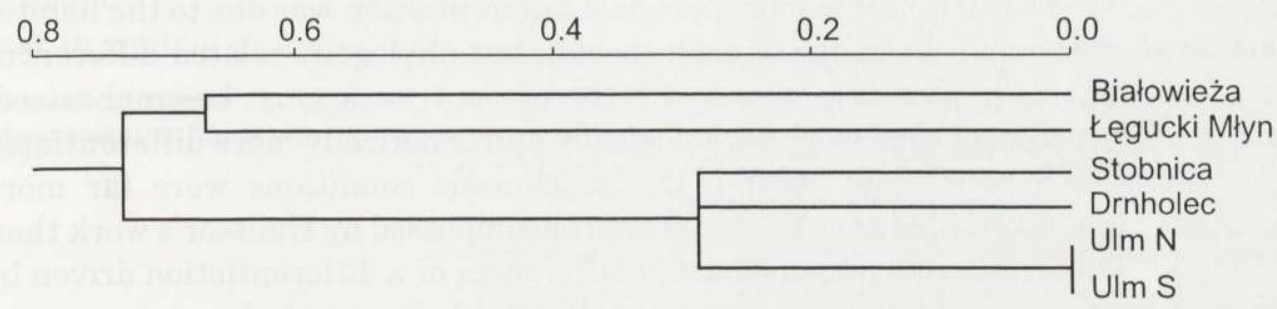

\section{C residual morphological distances}

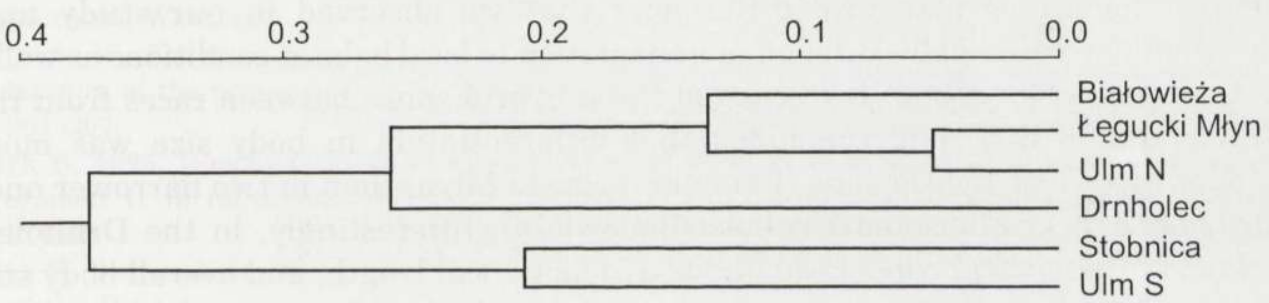

Fig. 4. UPGMA dendrograms of the global morphological distances (A), the chromosomal distances (B) and the residual morphological distances among races of Sorex araneus after removing the effect of the geoclimatic factors $(C)$. The cophenetic correlations between these dendrograms and the distance matrices are: $r_{\text {coph }}=0.813$ for $\mathrm{A}, r_{\text {coph }}=0.981$ for $\mathrm{B}$, and $r_{\text {coph }}=0.659$ for $\mathrm{C}$.

hypothesis. For instance, the differences in mandibular morphology between the Białowieża (EEKG) and Drnholec races (WEKG) were not substantially larger than the differences between the two samples belonging the Ulm race (WEKG) (see Fig. 1). W. Bogdanowicz and Z. Pucek (unpubl.) obtained very similar results. These authors found no obvious relationship between the six skull measurements of specimens of $S$. araneus in Poland and their karyological grouping. Searle and Thorpe (1987) did not observe any significant mandibular dissimilarity between the karyotypic races of $S$. araneus in Britain, either. 
It is often assumed that populations differentiate at the chromosomal level without associated morphological changes. If this is true, then minor morphological differences reported here can neither be treated as a by-product of chromosomal speciation nor as a consequence of the chromosomal transformations of White's $(1968,1978)$ stasipatric model. According to Wójcik (1993) and Searle and Wójcik (1998) the distribution of metacentrics in karyotypic races of $S$. araneus in Poland fits the stasipatric model or, more appropriately, the chain processes variant of that model, which was developed to explain the accumulation and geographic spread of Robertsonian fusions in the house mouse (White 1978).

Hausser (1984) studied four morphologically similar species of shrews in southern Europe: Sorex araneus, S. coronatus, S. granarius and S. samniticus. A large part of their interspecific morphological differentiation was due to the habitat conditions present in the range of each species, but phylogeny-related differences were also apparent. Two differences with the present work must be emphasized: first, the species concerned were karyologically and genetically more differentiated than the Polish races, and second, the geoclimatic conditions were far more contrasted and diversified over the large area encompassed by Hausser's work than in Poland. Thus, either phylogeny-related differences or a differentiation driven by selective pressure of the habitat may be undetectable in our study.

Significant intraspecific differences in dental morphology of karyological races of $S$. araneus in Scandinavia also seem to vary environmentally (Sulkava et al. 1985). The minor mensural differences that we observed in our study may represent chromosomally autonomous adaptation to local habitat conditions as well.

Chętnicki et al. (1996) investigated three hybrid zones between races from the EEKG and WEKG, and concluded that differentiation in body size was more evident in a wider hybrid zone (Drnholec/Lęgucki Młyn) than in two narrower ones (Drużno/Lęgucki Młyn and Drnholec/Białowieża). Interestingly, in the Drnholec/ /Lęgucki Młyn hybrid zone, head and body length, tail length, and overall body size of juvenile and adult shrews were larger but their body masses were lower than in individuals belonging to pure karyotypic races (Chętnicki et al. 1996). These authors suggested that different karyological categories of shrews might have a different premating or migratory behaviour. Searle and Thorpe (1987) found small mensural differences between the Oxford/Hermitage hybrids and non-hybrid common shrews in Britain, and supposed that there might be non-additive genetic difference between the races. They concluded: "If so, it follows that selection pressure for a particular mandible shape within a geographic region is sufficient for such a genetic difference to go undetected in comparisons between samples of different race". No effect of hybrid zones in our data matrix could be detected because all specimens examined belonged to pure chromosome races. In addition, recent results obtained by Fedyk et al. (2000) on the basis of meiotic analysis of hybrids in eastern Poland showed that it is the Drnholec race rather than the Stobnica race that makes contact with the Białowieża, Guzowy Młyn and Popieno races. In the light of this finding our samples Nos. 3 and 4 might belong to the 
Drnholec race instead of the Stobnica race (see Fig. 1). We found, however, no differences in mandibular morphology between these two races and their grouping had little or no effect on our results.

Nevertheless, morphological differentiation may be interpreted in the light of the established models of chromosomal speciation. For instance, Aguilera and Corti (1994) found that patterns of differentiation in cranial and mandibular features in spiny rats of the genus Proechimys in Venezuela were consistent with a phylogenetic hypothesis suggesting successive events of speciation coupled with an increase in diploid chromosome numbers (see also Reig et al. 1980).

In conclusion, we suggest that karyotypic divergence plays no important role in differentiating mandibular morphology in chromosome races of $S$. araneus, and geography is more important than karyotype as a morphological determinant, at least in central and western Europe.

Acknowledgements: We thank J. Hausser and J. B. Searle for their helpful comments and English improvement on the early draft of this paper.

\section{References}

Aguilera M. and Corti M. 1994. Craniometric differentiation and chromosomal speciation of the genus Proechimys (Rodentia: Echimyidae). Zeitschrift für Säugetierkunde 59: 366-377.

Atlas Klimatyczny Polski 1971. Część tabelaryczna. Zeszyty 2, 3, 4. Wydawnictwa Komunikacji i Łączności, Warszawa.

Chçtnicki W., Fedyk S., Banaszek A., Szałaj K. A. and Ratkiewicz M. 1996. Morphometrical characteristics of the common shrews (Sorex araneus L.) from interracial hybrid zones. Hereditas 125: 201-207.

Fedyk S. 1995. [Regional differentiation and hybrid zones between chromosomal races of Sorex araneus L. in north-eastern Poland]. Dissertationes Universitatis Varsoviensis 439: 1-125. [In Polish]

Fedyk S., Banaszek A., Chętnicki W., Cichomska A. and Szałaj K. A. 2000. Reassessment of the range of the Drnholec race: studies on meiosis in Sorex araneus hybrids. [In: Evolution in the Sorex araneus group: Cytogenetic and molecular aspects. J. B. Searle and J. M. Wójcik, eds]. Acta Theriologica 45, Suppl. 1: 59-67.

Frykman I., Simonsen V. and Bengtsson B. O. 1983. Genetic differentiation in Sorex. I. Electrophoretic analysis of the karyotypic races of Sorex araneus in Sweden. Hereditas 99: 279-292.

Hausser J. 1984. Genetic drift and selection: their respective weights in the morphological and genetic differentiation of four species of shrews in Southern Europe (Insectivora, Soricidae). Zeitschrift für zoologische Systematik und Evolutionsforschung 22: 302-320.

Hausser J. and Jammot D. 1974. Etude biométrique des mâchoires chez les Sorex du groupe araneus en Europe continentale (Mammalia, Insectivora). Mammalia 38: 324-343.

Homolka M. 1980. Biometrischer Vergleich zweier Populationen Sorex araneus. Acta Scientiarum Naturalium, Brno 14 (10): 1-34.

MacArthur R. H. 1957. On the relative abundance of bird species. Proceedings of the National Academy of Sciences of the USA 43: 293-295.

Norušis M. J. 1993. SPSS for Windows. Release 6.0. SPSS Inc., Chicago.

Pucek Z. 1970. Seasonal and age change in shrews as an adaptive process. [In: Variation in mammalian populations. R. J. Berry and H. N. Southern, eds]. Symposia of the Zoological Society of London 26: 189-207. 
Ratkiewicz M., Supruniuk J., Fedyk S., Banaszek A., Chętnicki W. and Szałaj K. A. 2000. Genetic differentiation and gene flow between the Drnholec and Lçgucki Młyn chromosome races of the common shrew Sorex araneus in northern Poland. [In: Evolution in the Sorex araneus group: Cytogenetic and molecular aspects. J. B. Searle and J. M. Wójcik, eds]. Acta Theriologica 45, Suppl. 1: 79-91.

Reig O. A., Aguilera M., Barros M. A. and Useche M. 1980. Chromosomal speciation in a rassenkreis of Venezuelan spiny rats (genus Proechimys, Rodentia, Echimyidae). Genetica 52/53: 291-312.

Rogers D. G. and Tanimoto T. T. 1960. A computer program for classifying plants. Science 132: $1115-1118$.

Rohlf F. J. 1993. NTSYS-pc. Numerical taxonomy and multivariate analysis system. Version 1.80. Exeter Software, New York.

Searle J. B. 1985. Isoenzyme variation in the common shrew (Sorex araneus) in Britain, in relation to karyotype. Heredity 55: 175-180.

Searle J. B. and Thorpe R. S. 1987. Morphometric variation of the common shrew (Sorex araneus) in Britain, in relation to karyotype and geography. Journal of Zoology, London 212: 373-377.

Searle J. B. and Wójcik J. M. 1998. Chromosomal evolution: the case of Sorex araneus. [In: Evolution of shrews. J. M. Wójcik and M. Wolsan, eds]. Mammal Research Institute, Polish Academy of Sciences, Białowieża: 219-268.

Sokal R. R. and Sneath P. H. A. 1963. Principles of numerical taxonomy. Freeman, San Francisco: $1-359$.

Sulkava S., Vahtola M. and Fredga K. 1985. Structure of the upper tooth-row of Sorex araneus in Scandinavia. Acta Zoologica Fennica 173: 237-239.

White M. J. D. 1968. Models of speciation. Science 159: 1065-1070.

White M. J. D. 1978. Chain processes in chromosomal speciation. Systematic Zoology 27: 285-298.

Wójcik J. M. 1993. Chromosome races of the common shrew Sorex araneus in Poland: a model of karyotype evolution. Acta Theriologica 38: 315-338.

Wójcik J. M. and Wójcik A. M. 1994. Protein variation in the common shrew (Sorex araneus L.) in Poland, in relation to karyotype. Folia Zoologica 43, Suppl. 1: 53-61.

Zima J., Lukáčová L. and Macholán M. 1998. Chromosomal evolution of shrews. [In: Evolution of shrews. J. M. Wójcik and M. Wolsan, eds]. Mammal Research Institute, Polish Academy of Sciences, Białowieża: 175-218.

Received 28 December 1999, accepted 9 March 2000. 